\title{
Patterns of divergence in fish species separated by the Isthmus of Panama
}

\author{
Christine E. Thacker
}

\begin{abstract}
Background: The Pleistocene closure of Isthmus of Panama, separating the basins of the Eastern Pacific and the Caribbean Sea, created a unique natural experiment that reveals how marine faunas respond to environmental change. To explore how fishes have been affected by this tectonic event, I compare transisthmian patterns in phylogeny and morphology for geminate lineages in two families, Eleotridae (sleepers) and Apogonidae (cardinalfishes).

Results: Time-calibrated phylogenies for these families show different diversification patterns. In Eleotridae, several independent shallow instances of transisthmian divergences occur, with one or a few species on either side of the Isthmus. Among Apogonidae, a single clade of Eastern Pacific species is nested within a broad Caribbean radiation that also includes a species known from the Mediterranean. Divergence time estimates for taxa isolated by closure of the Isthmus are broadly congruent. Hypotheses dated with deeper, fossil-based legacy calibrations put the divergences in the Miocene at 7.4-15.1 Ma, while those estimated with a shallow biogeographic calibration of final Isthmus closure range from 5.1 to $9.9 \mathrm{Ma}$, in the late Miocene/early Pliocene. Eleotridae are more euryhaline than Apogonidae, but do not exhibit shallower transisthmian divergences. In both families, descendent lineages on either side of the Isthmus of Panama exhibit significant shape differences, although that distinction disappears for Apogonidae when I apply a correction for phylogenetic relationships. To evaluate the tempo and mode of continuous character evolution, I fit several single and multiple rate evolutionary models to morphometric data reconstructed on the Apogonidae phylogeny. I find that the most highly favored model, as estimated on both legacy and isthmus calibrated hypotheses, is a multiple rate Ornstein-Uhlbeck model, with a mosaic of rate shifts postulated for shape changes among fishes in the Caribbean and Eastern Pacific.

Conclusions: Although many transisthmian taxa have been compared and their phylogenies calibrated to estimate the dates associated with population sundering, few studies correlate these timing estimates with morphological change. I show that in transisthmian fish lineages, morphometric distinctions are detectable across the Isthmus, and that rates and patterns of shape change have also shifted, with variable manifestations across the body and between the Caribbean and Eastern Pacific.
\end{abstract}

Keywords: Isthmus of Panama, Divergence time extimates, Rate shifts

\section{Background}

Complex interaction between organismal morphology and environment yields the tremendous scope of variation displayed across the tree of life. Underlain by genetics and mediated by selection, evolutionary changes in response to environmental conditions are at the core of comparative biology. Examining and understanding how morphology covaries with environment requires comparison of species in different habitats and evaluation of their similarities and

\section{Correspondence: thacker@nhm.org}

Research and Collections, Section of Ichthyology, Natural History Museum of Los Angeles County, 900 Exposition Blvd, Los Angeles, CA 90007, USA differences. In marine areas, organismal ranges are often wide, with diffuse boundaries, making finer-scale contrasts difficult. However, the world ocean is divisible into broad regions, each with distinct environments and faunas. Comparisons between these regions can inform understanding of broad-scale historical and evolutionary patterns in marine organisms. A prime example of neighboring marine environments separated relatively recently into disparate ecotopes is the division of the Eastern Pacific from the Caribbean Sea by the closure of the Isthmus of Panama.

The Isthmus of Panama is one of the most familiar and well-studied examples of a land barrier separating 
marine environments. Linking North and South America, this land bridge sundered the Eastern Pacific from the Caribbean Sea gradually over a period of 12 million years, finally closing completely in the Pleistocene, three to four million years ago (Ma; [1]). Establishment of this land bridge not only split marine populations, it also altered their habitats. After the closure, tropical currents in the Caribbean no longer flowed to the west and were instead deflected northward, causing increases in both salinity and temperature, and strengthening the Gulf Stream in the Atlantic. The Eastern Pacific, sealed off from its input of tropical ocean waters, cooled and became nutrient-rich due to deep water upwelling off the Central American coast [2-4]. These dramatic ecological changes likely resulted in extinctions in both oceans, and left behind geminate lineages that then further diverged.

The genetic signature of Isthmus closure is detectable throughout transisthmian clades, although interestingly the divergence dates for geminate lineages vary. Among the marine organisms surveyed, a minority have inferred split dates at (or sometimes after) the final Isthmus closure. More commonly, the genetic pattern is consistent with population separation in the 10 million years prior to final closure, during the gradual uplift and assembly of the Isthmus in the late Miocene [3-5]. Although many studies have considered the genetic divergence of geminate transisthmian taxa, few have examined the phenotypic consequences of the vicariance and ecological shifts precipitated by Isthmus closure. Previous work on the mojarra genus Diapterus [6] indicated that species separated by the Isthmus of Panama were morphometrically separable in some but not all cases, and analysis of size evolution across the Isthmus among snooks (Centropomus) did not reveal a consistent transisthmian pattern [7]. Outside fishes, geminate arcid bivalve species are not completely separated in morphospace, but are morphometrically distinguishable in most (84\%) cases [8]. Environmental changes following closure of the Isthmus affected the entire marine fauna, naturally assembling a wide-scale marine evolutionary experiment, but the responses of marine taxa to these tectonic changes have been gradual and complex.

The aims of this study are to examine representatives of lineages separated by the Isthmus of Panama, to evaluate when and in what ways they have diverged, and to determine whether or not divergence rates or patterns changed following the uplift of the Isthmus. I selected taxa from two acanthomorph fish families, Eleotridae and Apogonidae, both in the order Gobiiformes. Eleotridae (sleepers) are generally euryhaline, inhabiting brackish and freshwaters as well as nearshore marine environments; Apogonidae (cardinalfishes) are fully marine and associated with nearshore benthic habitats. For Eleotridae I focused on geminate pairs in the genera Dormitator,
Eleotris, Gobiomorus, and Leptophilypnus. These genera are phylogenetically distinct and represent all of the three New World eleotrid clades [9]. Apogonidae manifest a different phylogenetic pattern, with a single primarily New World clade including Apogon species, as well as all members of the genera Astrapogon, Phaeoptyx, Paroncheilus and Zapogon. The New World Apogonidae clade is composed of a broad Caribbean radiation with an Eastern Pacific clade nested within it, and including a single species that inhabits the Mediterranean Sea [10, 11]. For these taxa, I sampled throughout the New World clade, including the Mediterranean species.

I used an integrated morphological and molecular approach to evaluate transisthmian evolutionary patterns among Apogonidae and Eleotridae. For each group, I assembled and calibrated a phylogeny, in order to date the transisthmian splits for each geminate pair as well provide an evolutionary framework for the pattern of morphological change. To investigate how calibration can affect the inferred dates, as well as subsequent comparative analyses of shape change, I calibrated the phylogenies in two ways. First, I used divergence dates for deep nodes in the tree, derived from previous fossil-calibrated phylogenies (legacy calibration). In a second analysis, I calibrated shallow nodes of transisthmian relatives with a minimum date of 3.1 Ma, the time of the final closure of the Isthmus of Panama (isthmus calibration).

To assess change in form among species and between regions, I used geometric morphometrics. I digitized a suite of 17 external morphological landmarks among transisthmian relatives to measure shape variation and gauge whether and in what ways the transisthmian lineages have diverged. For nonindependent (phylogenetically nested) transisthmian clades, I applied phylogenetic corrections to the morphometric data to account for common ancestry. I also applied and compared single and multiple rate models to the morphometric characters reconstructed on the calibrated phylogenies, to ascertain whether or not rates or modes of phenotypic change shifted following closure of the Isthmus of Panama and resultant environmental changes in both ocean basins. I performed all the phylogenetically corrected analyses on both the legacy calibrated and the isthmus calibrated hypotheses, to evaluate the effect of the different calibration regimes.

\section{Methods}

\section{Phylogenetic reconstruction and calibration}

To infer phylogeny for Eleotridae and Apogonidae, I assembled previously published DNA sequence data and used Bayesian methods for both phylogenetic analysis and time-calibration with fossil-based legacy dates. For Eleotridae I used the matrix of [9], including Rhyacichthyidae, Odontobutidae, Milyeringidae, Butidae, and Eleotridae. 
The dataset includes sequence from the mitochondrial genes cytb, COI, ND1, and ND2, totaling 4397 base pairs for 78 taxa. That phylogeny [9] inferred that there are three clades of New World taxa within Eleotridae, of which two are sisters, consistent with two separate invasions of New World waters. Resolution among the major clades within the family was weakly supported. For this study I have included a wide range of gobiiform taxa, both to provide phylogenetic context for the New World taxa as well as to permit assignment of fossil calibrations to the tree. I also provide a Bayesian analysis of the [9] dataset, which was originally analyzed with parsimony. Eleotrid genera containing or entirely consisting of New World species are Dormitator, Eleotris, Gobiomorus, Guavina, Hemieleotris, Leptophilypnus and Microphilypnus. I use the genus name Eleotris for E. armiger and E. smaragdus, species often placed in the genus Erotelis, in line with the phylogenetic evidence indicating that Erotelis is nested within Eleotris [9, 12,13]. Of the New World eleotrid genera, all except for Microphilypnus (known from Venezuela and Brazil) have representatives on both sides of the Isthmus of Panama. For this study, all genera are present in the phylogeny, but representatives of transisthmian geminate pairs were only available for Dormitator, Eleotris, Gobiomorus, and Leptophilypnus. Sequences used for phylogenetic analysis of Eleotridae are given in Additional file 1: Table S1.

For Apogonidae, I analyzed a subset of the matrix of [10], including both mitochondrial (COI) and nuclear (ENC1, RAG1) genes, for a total of 3600 aligned base pairs for 26 taxa. Previous phylogenies of Apogonidae have varied in the depth of their sampling, but all agree in grouping New World and Mediterranean Apogon with Astrapogon, Paroncheilus, Phaeoptyx, and Zapogon, as part of a fairly deep split in the apogonid tree [10, 11, 14]. For this analysis, I included all the Apogon, Astrapogon, Paroncheilus, Phaeoptyx, and Zapogon sequenced by [10], as well as Gymnapogon vanderbilti and Pseudamia gelatinosa, used as outgroups and to provide deep enough nodes for calibrating the hypothesis. Sequences used for phylogenetic analysis of Apogonidae are listed in Additional file 1: Table S2.

I assembled the matrices using Geneious version 6.1.8 and Mesquite version 3.0.4, and aligned the protein coding genes based on the translated amino acid sequence. I then used MrBayes, version 2.0.9 to infer the Bayesian phylogeny (implemented in Geneious). For that analysis, I specified models independently for each gene partition. I applied a $\mathrm{HKY}+\mathrm{G}+\mathrm{I}$ substitution model for the COI partition and a GTR + G + I model, independently, for each of the cytb, ND1, and ND2 gene partitions in Eleotridae. Similarly, I used the GTR + G + I model for each of the COI and RAG1 gene partitions and SYM + G + I for the ENC1 gene partition in Apogonidae (as chosen by the $\mathrm{R}$ module phangorn [15]). I ran the analysis for $10.0 \times 10^{7}$ generations, with four simultaneous chains, sampling every 1000 replications, and discarding the first $10 \%$ of trees as burn-in. I constructed a $50 \%$ majority-rule consensus phylogeny of the remaining trees, then calibrated that phylogeny with Beast 1.7.5 [16], run with an uncorrelated lognormal relaxed clock model and a birth/death speciation prior.

To assign calibrations to the hypotheses, I first used dates inferred based on fossil calibrations in previous, more deeply sampled phylogenies. The use of such secondary calibration points has been questioned, particularly when they are assigned without error [17, 18], and one study showed that assignment of secondary calibrations results in small (1-2 Ma) but significant differences among subsamples of simulated phylogenies [19]. For these data, another possible method of calibration is to assign the node subtending the least divergent transisthmian lineages a biogeographic calibration, based on the date of the closure of the Isthmus of Panama. The use of biogeographic calibrations has also been criticized [20-22], in particular the assumptions that the date of a biogeographic event is reliably known and that no extinction has occurred since then that could result in the calibration being applied erroneously. Both calibration methods have their drawbacks, but because it is instructive to compare them, I performed a second calibration analysis for each family, with the shallowest (or only) transisthmian lineage in each group assigned a minimum divergence of 3.1 Ma.

For the legacy calibrated analyses, I applied calibrations for three nodes in Eleotridae: Butidae (47 Ma), Eleotridae (46 Ma), and the clade containing (Odontobutidae, Milyeringidae, Butidae, Eleotridae: $65 \mathrm{Ma}$ ). These calibrations were derived from the larger-scale analysis of Gobiiformes in [23], and I applied them as normal priors, with standard deviations of $10 \mathrm{Ma}$, more than encompassing the 95\% highest posterior densities of the calibration estimates in the original analysis. For Apogonidae, I dated the root of the family based on the calibrated gobiiform phylogeny of [23], at $51 \mathrm{Ma}$, also applied as a normal prior with a conservative $10 \mathrm{Ma}$ standard deviation. The Bayesian search ran for $10.0 \times 10^{8}$ generations (Eleotridae) or $10.0 \times 10^{9}$ generations (Apogonidae), with trees sampled every 1000 or 10,000 generations, respectively, and resulting in a pool of 100,000 trees. At the end of the analyses, estimated effective sample sizes (ESS) for all parameters exceeded 200 for Eleotridae, and all save the overall posterior and prior for Apogonidae (ESS of 171 and 169, respectively), likely due to weakly supported resolution along part of the phylogenetic backbone. I confirmed that $10 \%$ was the appropriate burn-in fraction with Tracer 1.5, then constructed a maximum clade credibility consensus of the post burn-in trees using TreeAnnotator 1.7.5 [16], and visualized this tree using FigTree 1.3.1 [24]. For the isthmus calibrated analyses, I assigned a lognormal prior for the youngest transisthmian split in Eleotridae, between Dormitator species, 
and for the origin of the Eastern Pacific clade in Apogonidae. For each calibration, I specified an offset of 3.1 (representing the hard minimum of $3.1 \mathrm{Ma}$ for transisthmian divergences), and standard deviation of 1.0. I ran and sampled these analyses as for the legacy calibrated hypotheses, and in both cases, ESS values well exceeded 200. I also constructed and visualized the consensus hypothesis as described above for the legacy calibrated hypotheses.

\section{Morphometric data and analyses}

To quantify phenotypic variation between geminate species, I examined preserved specimens of Eleotridae in each of the six species comprising the three geminate pairs in Eleotris, Dormitator, and Gobiomorus. Leptophilypnus, the other geminate pair present in the phylogenetic analysis, was not used for shape comparisons because adults of Leptophilypnus are too small (maximum $64 \mathrm{~mm}$ SL, most much smaller [25]) to be reliably photographed and landmarked. For Apogonidae, I examined representatives of the entire New World clade, including Caribbean species, the Mediterranean singleton Apogon imberbis, and the clade of Eastern Pacific taxa. Species and specimens examined are listed in Additional file 1: Table S3; individuals were initially fixed in formalin and preserved in $70 \%$ ethanol. I examined 75 individuals of Eleotridae (range of six to 16 individuals for each of the six species) and 157 individuals of Apogonidae (range of two to 11 individuals for each of 25 species, including several not present in the molecular phylogeny). In every case, I selected unbent, intact adults. For each individual, I photographed the specimen using a Panasonic Lumix DMC-ZS3 digital camera mounted on a copystand. I then digitized a suite of 17 landmarks from the left side of each individual (Fig. 1), using ImageJ version $1.49 \mathrm{t}$ [26]. These landmarks primarily describe the shape of the body, including the placements of the median fins, but also include the dimensions of the mouth and eyes, the anterior extent of the opercular opening, and the positions of the pelvic and pectoral fins. All landmarks were assigned in all specimens.

To determine whether or not Caribbean and Eastern Pacific taxa among Apogonidae and Eleotridae are separated in shape space, I used MorphoJ version 1.05d [27]. I forwarded landmark coordinates to MorphoJ, where I performed a Procrustes fit, generated a covariance matrix, and used that matrix as data for principal components analysis (PCA) and canonical variates analysis (CVA). For the CVA, I grouped the individuals by geographic range. I also used MorphoJ to generate plots of the PCA for both sleepers and cardinalfishes. To evaluate whether or not the shape differences among transisthmian taxa are significant, I performed Procrustes PCA and MANOVA on the morphometric landmark data with range as a factor, using the $\mathrm{R}$ (version 3.2.1) package geomorph (version 2.1.5 [28]).

\section{Phylogenetic comparative analyses}

The transisthmian divergences among Eleotridae are all phylogenetically independent. In contrast, among New World Apogonidae the Eastern Pacific radiation is nested inside a Caribbean clade, along with a single Mediterranean species. With this pattern, comparisons among species inhabiting different ranges are not independent, and so I used phylogenetic PCA and MANOVA to correct for shared evolutionary history. For these analyses, I used a reduced subset of the cardinalfish morphometric data that only included species present in the phylogenetic tree (17 species overlapped between the morphometric and phylogenetic analyses). Using that phylogeny, I first tested for phylogenetic signal in the cardinalfish morphometric

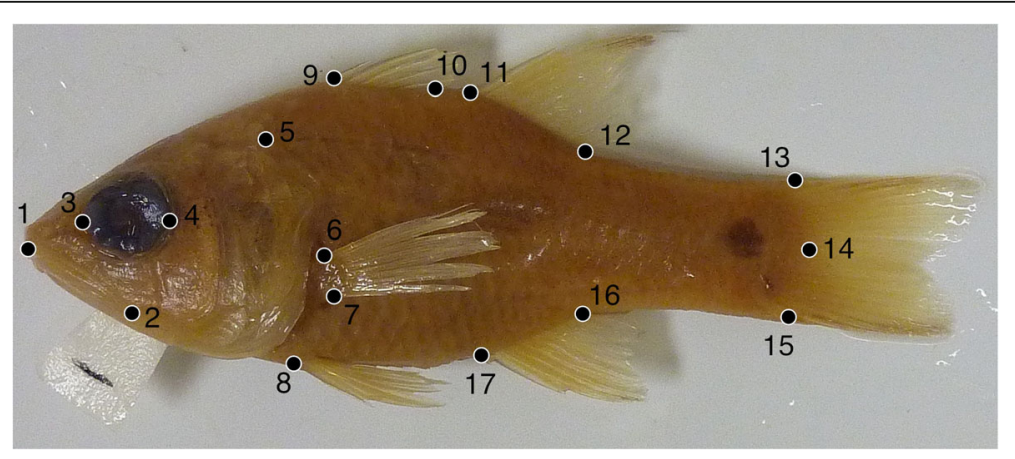

Fig. 1 Locations of morphometric landmarks, shown on left lateral view of Apogon imberbis (UF 225062). Landmarks digitized are: (1) anterior tip of premaxilla, (2) posteroventral tip of maxilla, (3) anterior edge of eye, (4) posterior edge of eye, (5) anterior extent of opercular opening, (6) dorsal extent of pectoral fin base, (7) ventral extent of pectoral fin base, (8) anterior extent of pelvic fins, (9) base of anteriormost dorsal spine in first dorsal fin, (10) base of posteriormost dorsal spine in first dorsal fin, (11) base of anteriormost dorsal spine in second dorsal fin, (12) base of posteriormost dorsal ray of second dorsal fin, (13) dorsal tip of caudal fin hypurals, (14) center of caudal fin hypurals, (15) vental tip of caudal fin hypurals, (16) base of posteriormost anal fin ray, (17) base of first anal spine 
data with geomorph. I then performed a phylogenetic MANOVA two ways. First, using the uncorrected PC scores for the reduced taxon set, I executed a phylogenetic MANOVA of shape change by range with the geiger package (version 2.0.6 [29]), and assessed significance of range as a factor using the Wilks test. Then, I generated a phylogenetic PCA of the shape coordinates for the reduced taxon set with the phytools package (version 0.5-20 [30]). Finally, I performed a phylogenetic MANOVA of the phylogenetically corrected PC scores, again using geiger.

To gauge whether or not the rate or mode of phenotypic change in Apogonidae shifted across the phylogeny when lineages were sundered by closure of the Isthmus of Panama, I used the R package $m v M O R P H$ [31]. I reconstructed the evolution of geographic range (Caribbean, Eastern Pacific, or Mediterranean) on the calibrated phylogeny, as well as scores for the first three PC axes, and then fitted multivariate models of trait evolution to the reconstructions. I first calculated the fit of single and multiple rate Brownian Motion (BM; trait variance increases over time, without constraint) and OrnsteinUhlbeck (OU; trait variance is constrained about a mean, emulating selection) models across the phylogeny. Then, I imposed models incorporating mode shifts at the closure of the Isthmus of Panama (separation of the Eastern Pacific clade from the Caribbean radiation). I applied six mode shift models, the first four incorporating shifts between BM and OU modes: ecological release (shift from $\mathrm{OU} \rightarrow \mathrm{BM}$ process with same rate); release and radiate (shift from $\mathrm{OU} \rightarrow \mathrm{BM}$ process with variable rates); ecological constraint (shift from BM $\rightarrow$ OU process with same rate); and radiation and ecological constraint (shift from BM $\rightarrow$ OU process with variable rates [32]). These models emulate scenarios in which character evolution becomes more (ecological constraint) or less (ecological release) constrained following the splitting of populations by the closure of the Isthmus of Panama and associated environmental changes.

I also tested two models involving mode switches between BM and EB (early burst, a modification of the accelerating/decelerating rates $[\mathrm{ACDC}]$ model of character change in which the rate of evolution slows exponentially, emulating an adaptive radiation [33, 34]). These models are denoted Brownian motion/early burst (BMEB) and early burst/Brownian motion (EBBM) in [31], and in this context would describe adaptive radiations taking place before or after the populations were split by the Isthmus of Panama. Finally, I evaluated AIC and $\mathrm{AIC}_{\mathrm{c}}$ score values for each of the ten evolutionary models to assess the fits, and compared support among models using Akaike weights computed from the $\mathrm{AIC}_{\mathrm{c}}$ scores [35]. I performed each of these analyses on both the legacy calibrated and isthmus calibrated phylogenies, to compare the effects of different calibration regimes.

\section{Results}

Phylogeny and transisthmian divergences

The legacy and isthmus calibrated phylogenies inferred for Apogonidae are shown in Figs. 2 and 3, and for Eleotridae in Figs. 4 and 5; note the differing timescales and the larger error bars in the isthmus calibrated analyses. In both cases, the hypotheses generally agree well with previously published studies. For Apogonidae, the hypothesis agrees in all major respects with the relationships inferred in [10], including the presence of separate clades for Indo-Pacific and New World + Mediterranean Apogon, and the nesting of Astrapogon, Phaeoptyx, Paroncheilus, and Zapogon within the Apogon clade. The five Eastern Pacific Apogon species form a clade, and that clade is nested within the Atlantic and Mediterranean species of Apogon. The hypotheses differ slightly in the relationships among Phaeoptyx, Eastern

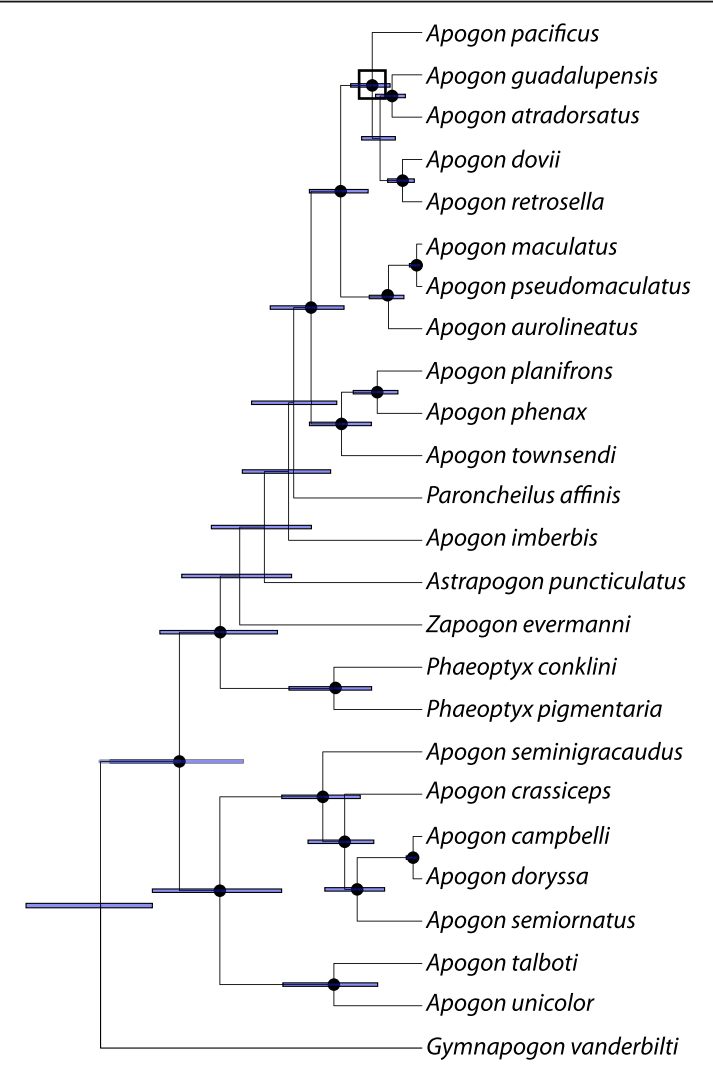

\begin{tabular}{|c|c|l|l|l|}
\hline Paleocene & Eocene & Oligocene & Miocene & Plio.
\end{tabular}

Fig. 2 Phylogeny of Apogonidae, based on fragments of one mitochondrial (COI) and two nuclear (ENC1 and RAG1) genes and calibrated with fossil-based legacy dates. Error bars indicate 95\% highest posterior density, and black circles at nodes indicate 95-100\% posterior probability. For compactness, the most distal outgroup, Pseudamia gelatinosa, is not shown. Colored bars indicate ranges: Caribbean = red, Eastern Pacific = green, Mediterranean = blue, IndoPacific $=$ purple. Black box at node indicates separation of lineages by the Isthmus of Panama 


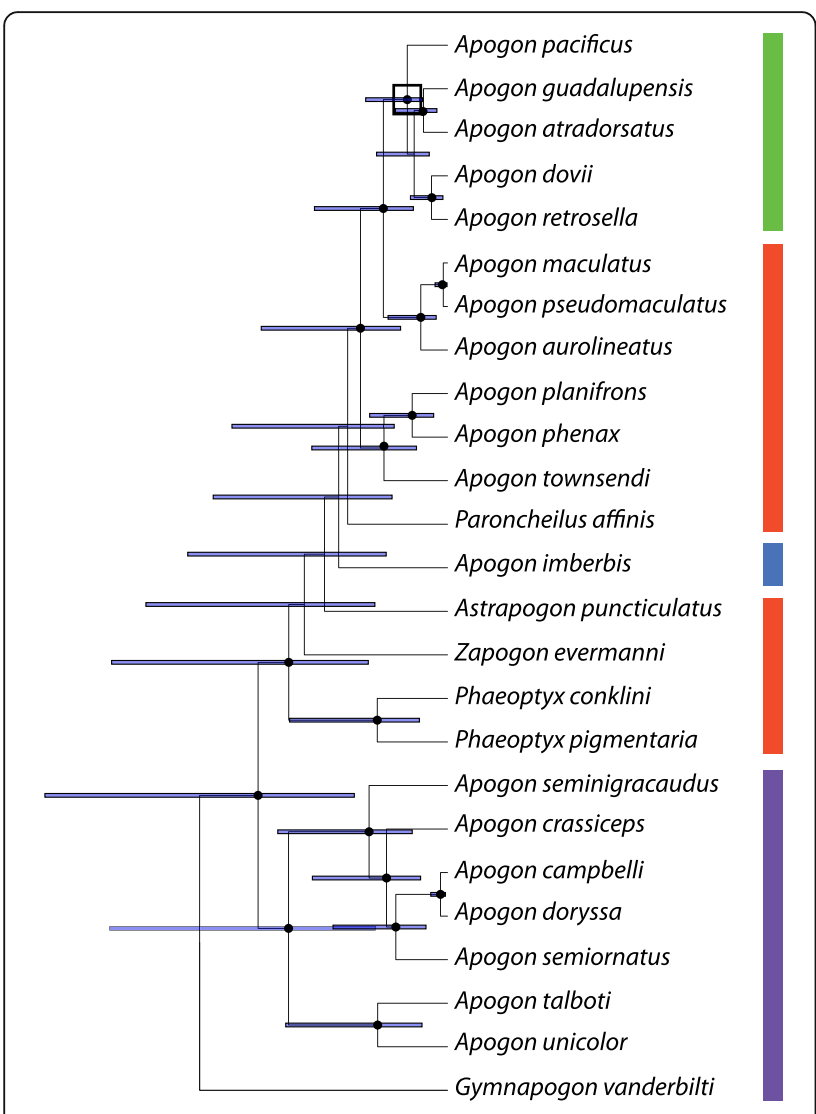

Fig. 3 Phylogeny of Apogonidae, based on fragments of one mitochondrial (COI) and two nuclear (ENC1 and RAG1) genes and calibrated with minimum date of closure of the Isthmus of Panama. Error bars indicate 95\% highest posterior density, and black circles at nodes indicate $95-100 \%$ posterior probability. For compactness, the most distal outgroup, Pseudamia gelatinosa, is not shown. Colored bars indicate ranges: Caribbean $=$ red, Eastern Pacific $=$ green, Mediterranean $=$ blue, Indo-Pacific $=$ purple. Black box at node indicates separation of lineages by the Isthmus of Panama

Pacific Apogon, A. aurolineatus, and the Mediterranean A. imberbis, generally where nodal support is the weakest.

Similarly, Eleotridae relationships recovered here are mostly congruent with those of $[9,12,13]$, but differ slightly along the backbones, areas of weaker support, particularly as compared to the parsimony-based analysis of [9]. This hypothesis resolves two New World clades, one including Eleotris, and a second containing Dormitator, Guavina, Hemieleotris, Gobiomorus, Microphilypnus, and Leptophilypnus. Transisthmian sister taxa of Eleotridae in this hypothesis are present in the genera Dormitator, Eleotris, Gobiomorus, and Leptophilypnus.

In both Apogonidae and Eleotridae, legacy calibrated phylogenies indicate that the New World lineages arose in the Oligocene, between 27.4-37.2 Ma, and that transisthmian splits were established across a range of divergences spanning 7.4-15.1 million years in the middle to late Miocene. The isthmus calibrated phylogenies indicate shallower divergence dates overall, with New World lineages postulated to have arisen from the latest Oligocene into the Miocene, between 16.2-24.2 Ma, and transisthmian splits occurring from 5.1 to $9.9 \mathrm{Ma}$ (late Miocene to early Pliocene; Table 1). Isthmus calibrated nodes have greater uncertainty than those in the legacy calibrated hypothesis, because the single, relatively young calibration estimate yields greater error deeper in the phylogeny, more distant from the calibrated node and in areas of weaker support. Multiple deeper legacy calibrations allow more precise dating estimates. The complementary median divergence times inferred in both phylogenies are within each other's error estimates, particularly among the more recent splits.

\section{Morphometric PCA, CVA, and MANOVA}

Results of the morphometric PCAs for Eleotridae are shown in Fig. 6. In Dormitator (Fig. 6a), PC1 and PC2 account for $32 \%$ and $16 \%$ of the total variance, and both describe changes in the depth of the head and body as well as the width of the head. Eleotris PC1 and PC2 are $31 \%$ and $20 \%$ of the total variance, with $\mathrm{PC} 1$ encompassing the relative elongation of the head, and PC2 describing the relative orientations of the head and caudal peduncle (Fig. 6b). For Gobiomorus, PC1 and PC2 account for $35 \%$ and $20 \%$ of the variance, $\mathrm{PC} 1$ accounts for relative displacement of the head and caudal peduncle, and PC2 describes changes in body depth and head shape (Fig. 6c). In all three geminate pair comparisons, shape differences between the species are slight, and eigenvalues for each PC are low (maximally 0.001). CVA for geminate pairs of Eleotridae resulted in each case with a single CV axis accounting for $100 \%$ of the variation, with wide separation among species in every comparison.

Morphometric PCA results for Apogonidae are presented in Fig. 7. Among cardinalfishes, the overlap among regions is more complete, with the more numerous Caribbean forms completely containing the variation among those in the Eastern Pacific and Mediterranean. The PC axes also describe more complex variation; PC1 (22\% of variation) encompasses a shift in body proportions with a deeper cranial portion, and a slight rotation of the caudal region. PC2 ( $17 \%$ of variation) is more easily interpretable as an enlargement of the head, and deepening and shortening of the posterior portion of the body. The CVA, in which the axes are oriented in order to maximize the differences among regions, shows more separation among the apogonid ranges (Fig. 8). Caribbean and Eastern Pacific species are separated on the CV1 axis, which primarily describes widening and enlargement of the head. All New World taxa are separated from the Mediterranean species on CV2, which describes narrowing of the 


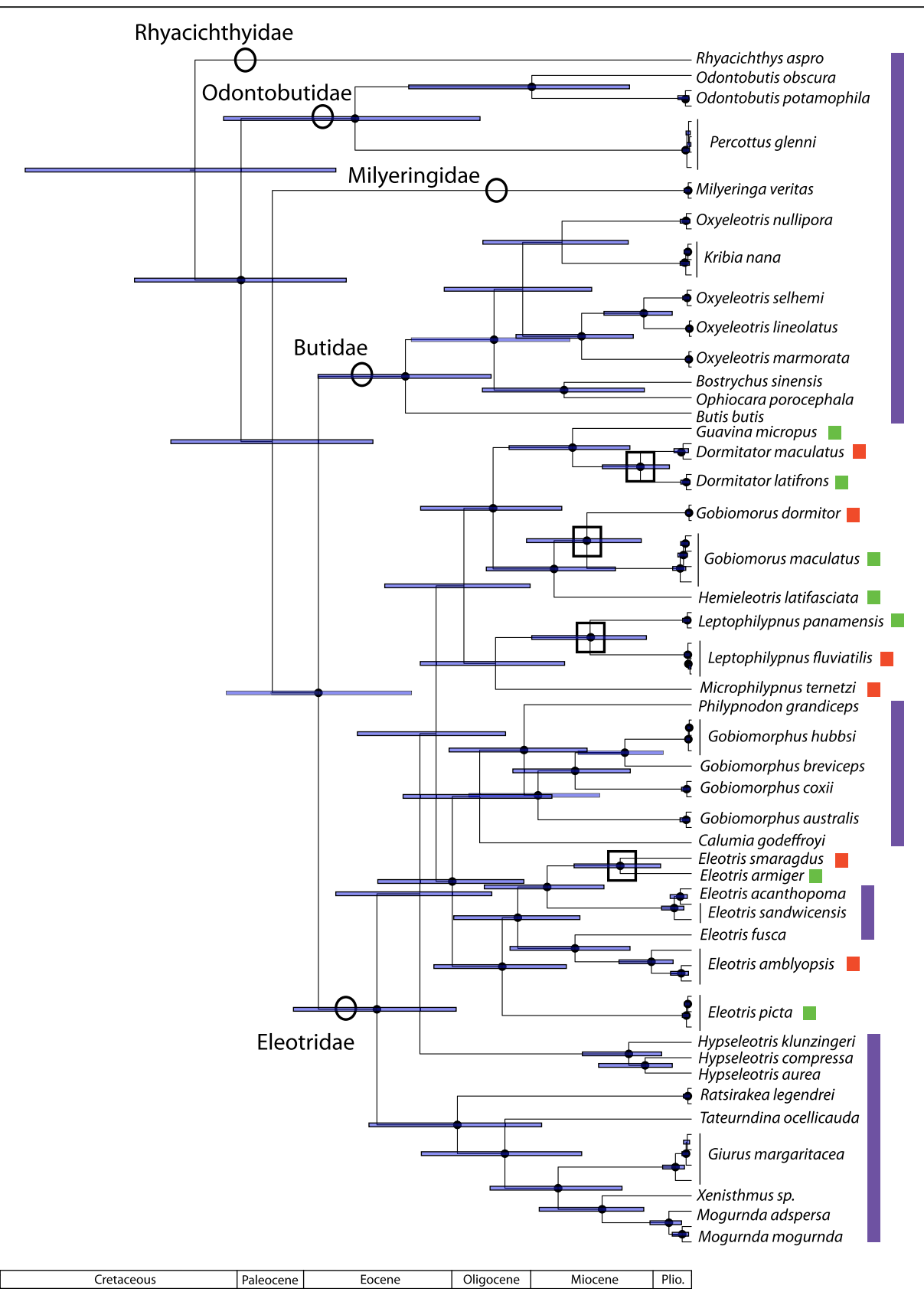

Fig. 4 Phylogeny of Eleotridae, based on four mitochondrial (cytb, COI, ND1, ND2) genes and calibrated with fossil-based legacy dates. Error bars indicate $95 \%$ highest posterior density, and black circles at nodes indicate $95-100 \%$ posterior probability. Familial classification is indicated on clades, and colored bars indicate ranges: Caribbean = red, Eastern Pacific $=$ green, Indo-Pacific $=$ purple. Black boxes at nodes indicate separation of lineages by the Isthmus of Panama. In the Eleotris clade, other geminate splits than the one examined here have occurred, but were not included in this analysis

posterior part of the body, most particularly the caudal peduncle.

Among the eleotrid genera, the first nine PC axes account for $91-94 \%$ of the total variance. MANOVA of PC1-PC9 for geminate species by range in Dormitator was highly significant $(p=0.001)$, significant in Eleotris $(p=0.015)$, and nearly significant for Gobiomorus $(p=0.07)$. In Apogonidae, twelve PC axes account for $91 \%$ of the variance. MANOVA of these axes among ranges (Caribbean, Eastern Pacific, and Mediterranean) was also highly significant $(p=0.001)$.

I detected phylogenetic signal among the shape data (PC scores) for Apogonidae based on the Kmult test $(p=0.031$ for both legacy and isthmus calibrated 


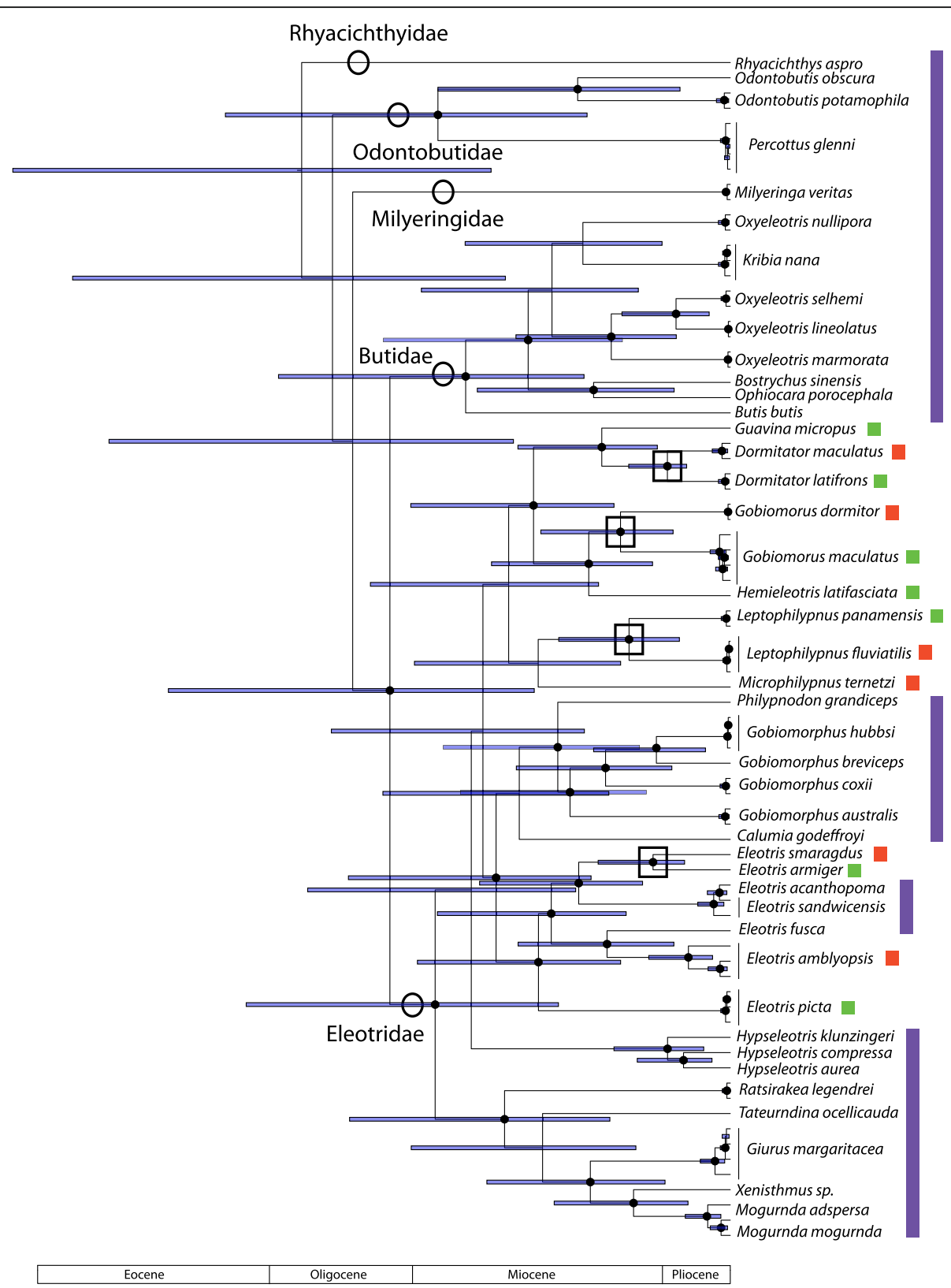

Fig. 5 Phylogeny of Eleotridae, based on four mitochondrial (cytb, COI, ND1, ND2) genes and calibrated with minimum date of closure of the Isthmus of Panama. Error bars indicate 95\% highest posterior density, and black circles at nodes indicate 95-100\% posterior probability. Familial classification is indicated on clades, and colored bars indicate ranges: Caribbean $=$ red, Eastern Pacific $=$ green, Indo-Pacific $=$ purple. Black boxes at nodes indicate separation of lineages by the Isthmus of Panama. In the Eleotris clade, other geminate splits than the one examined here have occurred, but were not included in this analysis

phylogenies). After phylogenetic correction, I found comparisons among ranges to be insignificant based on both a phylogenetic MANOVA of PC scores (first twelve PC axis scores, including $91 \%$ of variation and yielding $p=0.941$ for legacy calibrated phylogeny and $p=0.922$ for isthmus calibrated phylogeny), and a phylogenetic MANOVA of phylogenetically corrected PC scores (first three PC axis scores, accounting for 93\% of the variation, yielding $p=0.628$ for legacy calibrated phylogeny and $p=0.667$ for isthmus calibrated phylogeny, both assessed with the Wilks test). Results of MANOVAs are presented in Table 2.

\section{Analyses of phylogenetic rate and mode}

Of the models tested, the multiple rate Ornstein-Uhlbeck model was fitted with the highest log-likelihood, lowest $\mathrm{AIC}$ and $\mathrm{AIC}_{\mathrm{c}}$ scores, and by far the highest $\mathrm{AIC}$ weight. This model is consistent with selection on cardinalfish 
Table 1 Inferred ages in Ma and 95\% highest posterior density (in parentheses) for clades in Eleotridae and Apogonidae, determined from both legacy and isthmus calibrations. Eleotris and Dormitator/Gobiomorus clade ages are for the larger New World clades containing those genera

\begin{tabular}{lll}
\hline Node & Age - legacy & Age - isthmus \\
\hline Eleotridae: Dormitator maculatus/latifrons & $7.4(3.4-12.8)$ & $5.1(3.2-10.6)$ \\
Eleotridae: Eleotris smaragdus/armiger & $10.3(5.3-17.0)$ & $6.4(2.0-15.7)$ \\
Eleotridae: Gobiomorus dormitor/maculatus & $15.1(7.7-24.5)$ & $9.9(3.2-23.8)$ \\
Eleotridae: Leptophilypnus fluviatilis/panamensis & $14.6(6.8-23.6)$ & $9.2(2.7-22.3)$ \\
Apogonidae Eastern Pacific clade stem & $12.5(8.2-17.3)$ & $8.2(4.4-17.0)$ \\
Apogonidae Eastern Pacific clade crown & $7.6(4.9-10.9)$ & $5.1(3.1-10.5)$ \\
New World Eleotridae: Eleotris clade stem & $34.5(24.2-45.4)$ & $20.2(7.6-46.7)$ \\
New World Eleotridae: Eleotris clade crown & $27.4(18.1-37.2)$ & $16.3(5.6-37.7)$ \\
New World Eleotridae: Dormitator/Gobiomorus clade stem & $32.9(23.3-44.4)$ & $19.3(7.4-44.7)$ \\
New World Eleotridae: Dormitator/Gobiomorus clade crown & $28.7(18.7-39.1)$ & $17.2(6.8-39.8)$ \\
New World Apogonidae clade stem & $37.2(27.4-47.9)$ & $24.2(11.9-51.4)$ \\
New World Apogonidae clade crown & $31.0(22.2-40.3)$ & $20.28(10.12-42.92)$ \\
\hline
\end{tabular}

phenotypes throughout the period of Isthmus uplift, but with different rates before and after Isthmus closure. Loglikelihoods and AIC scores and weights for each of the legacy and isthmus calibrated phylogenies under the various models are given in Table 3 . The relative rates of trait evolution for the Eastern Pacific clade vs. the Caribbean radiation in the multirate Brownian motion model are similar, although differently localized. When calculated with the legacy calibrated phylogeny, rates of change for PC1 are nearly equivalent in the Caribbean and Eastern Pacific, while those of PC2 and PC3 are elevated in the Eastern Pacific. The mean rate of change across the three $\mathrm{PC}$ axes is also higher in the Eastern Pacific relative to the Caribbean. Results from calculation with the isthmus calibrated phylogeny are similar, with comparable rates indicated for PC1 in the Caribbean and Eastern Pacific, an elevated rate on PC3 in the Eastern Pacific as compared to the Caribbean, but a higher rate of change on PC2 in the Caribbean. The mean rate of change across the three PC axes is higher overall in the Caribbean under this calibration (Table 4).

\section{Discussion}

\section{Phylogenetic relationships and timing}

Phylogenetic patterns among New World Eleotridae and Apogonidae are different, with New World species more phylogenetically dispersed and with more separate, lower diversity instances of transisthmian divergence in Eleotridae as compared to Apogonidae. Seven transisthmian splits are scattered throughout Eleotridae; in Apogonidae, a single New World clade contains multiple species on either side of the Isthmus and includes a Mediterranean species. The species diversity in the New World for both groups is similar: 28 species in Eleotridae compared to 24 in Apogonidae. In Eleotridae, just one or a few species is found on either side of the Isthmus in each geminate split, but in Apogonidae, a single clade contains a broad Caribbean radiation, including a clade of Eastern Pacific species as well as a single Mediterranean species. A review of phylogenetic patterns among Atlantic fish taxa concluded that the apogonid pattern, with diversification taking place well after Isthmus closure rather than exclusively driven by it, is more common among reef fishes [2]. The resolution of a Mediterranean species among New World Apogonidae is consistent with transatlantic dispersal from west to east, as has been inferred for several lineages of reef fishes, including some gobies (close relatives of sleepers and cardinalfishes, [2, 36, 37]).

New World lineages of both Apogonidae and Eleotridae arose at roughly the same time, estimated from the legacy calibrated phylogeny at around 27.4-37.2 $\mathrm{Ma}$ in the Oligocene, and from the isthmus calibrated phylogeny at 16.3-24.2 Ma in the late Oligocene to Miocene (Table 1). Over most of this time, North and South America were well-separated, and Asia and Africa were as well, resulting in a continuous band of tropical ocean extending around the globe. Among Gobiiformes, several other instances of New World invasion from the east have occurred in both Gobiidae and Gobionellidae. In some cases (Stenogobius lineage of Gobionellidae, Priolepis and Glossogobius lineages of Gobiidae), species generally have wide ranges, and some include the Western Atlantic and/or Eastern Pacific. Among other lineages (Lophogobius, Gunnellichthys, and the entire Gobiosomatini, all in Gobiidae), larger New World radiations are present. New World invasions in Gobiidae and Gobionellidae have occurred over a wide span from the mid-Eocene (Gobiosomatini) through to the mid-Miocene, when the Terminal Tethyan Event (collision of Africa and Asia) closed off passage between the Indian Ocean and the Atlantic [38]. 

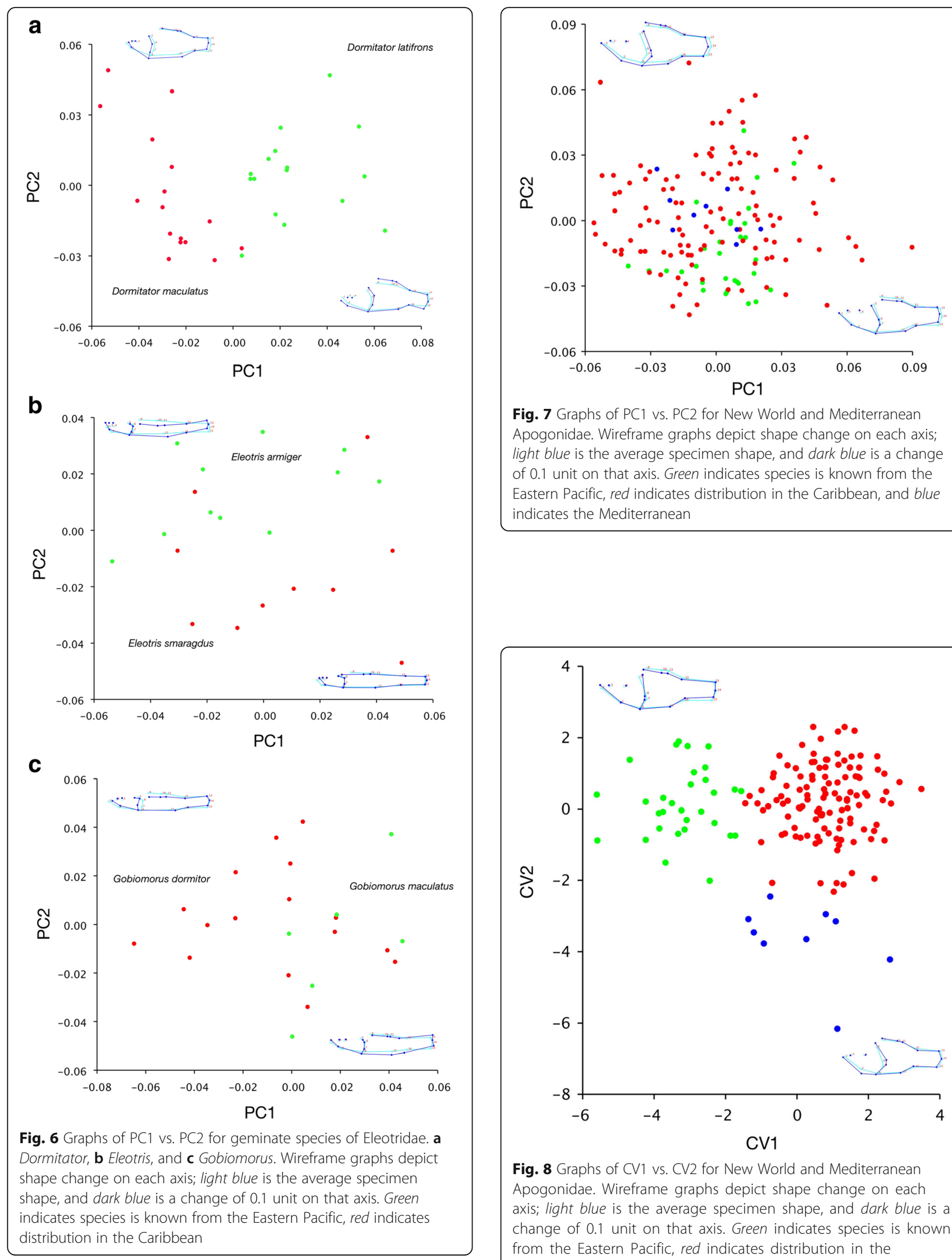

Fig. 7 Graphs of PC1 vs. PC2 for New World and Mediterranean Apogonidae. Wireframe graphs depict shape change on each axis; light blue is the average specimen shape, and dark blue is a change of 0.1 unit on that axis. Green indicates species is known from the Eastern Pacific, red indicates distribution in the Caribbean, and blue indicates the Mediterranean

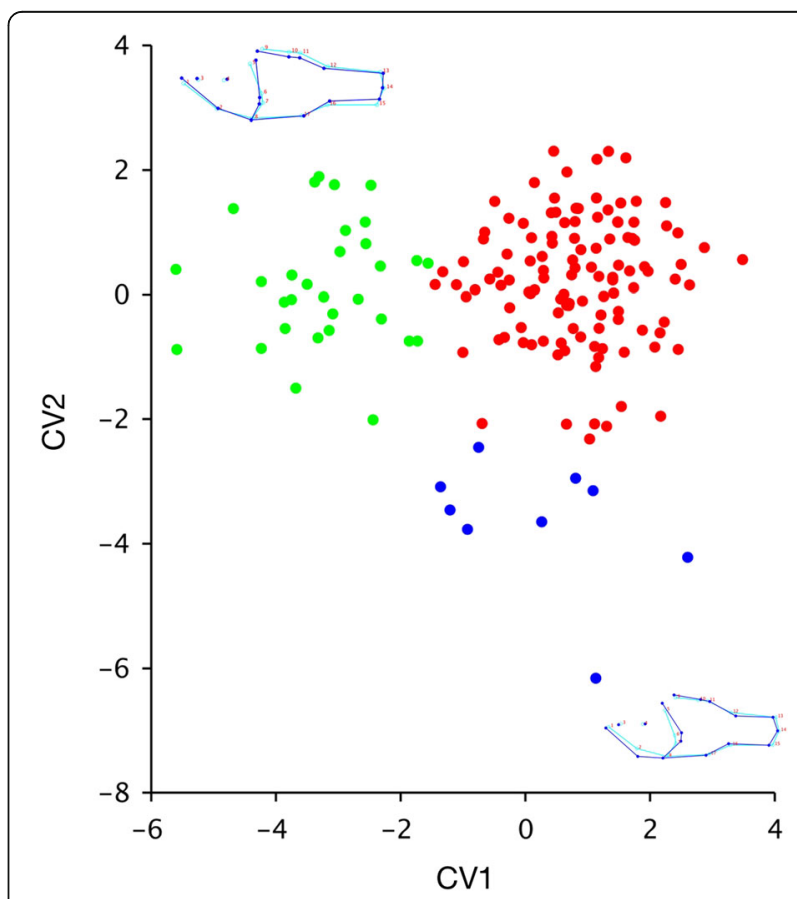

Fig. 8 Graphs of CV1 vs. CV2 for New World and Mediterranean Apogonidae. Wireframe graphs depict shape change on each axis; light blue is the average specimen shape, and dark blue is a change of 0.1 unit on that axis. Green indicates species is known from the Eastern Pacific, red indicates distribution in the Caribbean, and blue indicates the Mediterranean 
Table 2 Results of Procrustes MANOVA of morphometric shape change by range for transisthmian New World Eleotridae and Apogonidae, and phylogenetic MANOVA for both PC scores and phylogenetically corrected PC scores for Apogonidae

\begin{tabular}{lll}
\hline Taxon \& Analysis & $F$ & $P$ \\
\hline Procrustes MANOVA & & \\
Eleotridae: Dormitator & 10.584 & $\mathbf{0 . 0 0 1}$ \\
Eleotridae: Eleotris & 2.243 & $\mathbf{0 . 0 1 5}$ \\
Eleotridae: Gobiomorphus & 1.645 & 0.077 \\
Apogonidae & 5.472 & $\mathbf{0 . 0 0 1}$ \\
Phylogenetic MANOVA & & \\
Apogonidae (PC scores, legacy) & 1.661 & 0.941 \\
Apogonidae (PC scores, isthmus) & 1.661 & 0.921 \\
Apogonidae (corrected PC scores, legacy) & 1.366 & 0.628 \\
Apogonidae (corrected PC scores, isthmus) & 1.362 & 0.667 \\
\hline
\end{tabular}

Phylogenetic MANOVAs were calculated for both legacy and isthmus calibrated phylogenies. Significant $P$-values are shown in boldface
Splits among geminate lineages in Apogonidae and Eleotridae vary in their timing, but all occurred in the late Miocene to early Pliocene, estimated from the legacy calibrated phylogeny between 7.4 and 15.1 Ma, and from the isthmus calibrated phylogeny at 5.1-9.9 Ma (Table 1). These dates all predate the canonical date of final closure of the Isthmus of Panama at 3.1 Ma, but correspond roughly to one of the two dates inferred by [4] for marine vicariance associated with Isthmus uplift. In that study, a review of both marine and terrestrial data indicated that the Isthmus of Panama was established enough, even if it was not completely closed, to split marine populations at two times in the Miocene, first at $23 \mathrm{Ma}$ and then again at $7 \mathrm{Ma}$. Extinctions among transisthmian taxa following Isthmus closure may also affect the inference of split dates, with earlier divergences appearing to be geminates if closer relatives have since become extinct.

Among both Eleotridae and Apogonidae, the legacy calibrated estimates across the tree have lower error estimates (95\% highest posterior density) and are in much better agreement with previous phylogenies of gobiiformes $[23,28]$ as well as larger phylogenies of fishes [39-41]. The lower error estimates in the legacy calibrated phylogeny are

Table 3 Results of mvMORPH model fitting for transisthmian Apogonidae, showing log-likelihood (LnL), Akaike information criterion $(\mathrm{AIC})$, AIC corrected for limited sampling $\left(\mathrm{AIC}_{\mathrm{c}}\right)$, difference between $\mathrm{AIC}_{\mathrm{c}}$ and $\mathrm{AIC}$ of best fit model $(\triangle \mathrm{AIC})$, and $\mathrm{AIC}$ weight

\begin{tabular}{|c|c|c|c|c|c|}
\hline Model & $\mathrm{LnL}$ & $\mathrm{AlC}$ & $\mathrm{AlC}_{\mathrm{c}}$ & $\Delta \mathrm{AIC}_{\mathrm{c}}$ & $\mathrm{AlC}_{\mathrm{C}} \mathrm{Wt}$ \\
\hline \multicolumn{6}{|l|}{ Legacy calibrated phylogeny } \\
\hline Brownian motion single rate & 123.77 & -229.54 & -203.82 & 221 & 0.00 \\
\hline Brownian motion multiple rate & 130.51 & -219.03 & -403.83 & 20.99 & 0.00 \\
\hline Ornstein-Uhlbeck single rate & 134.9 & -239.91 & 240.09 & 664.91 & 0.00 \\
\hline Ornstein-Uhlbeck multiple rate & 141.01 & -240.02 & -424.82 & 0.00 & 0.99 \\
\hline Ecological release & 125.02 & -220.04 & 259.96 & 684.78 & 0.00 \\
\hline Release and radiate & 135.67 & -229.34 & -414.14 & 10.68 & 0.00 \\
\hline Ecological constraint & 119.64 & -209.28 & 270.72 & 695.54 & 0.00 \\
\hline Radiation \& ecological constraint & 126.43 & -210.86 & -395.66 & 30.16 & 0.00 \\
\hline Brownian motion/early burst & 122.50 & -225.01 & -188.34 & 236.48 & 0.00 \\
\hline Early burst/Brownian motion & 53.24 & -86.49 & -49.83 & 374.99 & 0.00 \\
\hline \multicolumn{6}{|l|}{ Isthmus calibrated phylogeny } \\
\hline Brownian motion single rate & 123.94 & -229.89 & -204.17 & 223.12 & 0.00 \\
\hline Brownian motion multiple rate & 131.21 & -220.42 & -405.22 & 22.07 & 0.00 \\
\hline Ornstein-Uhlbeck single rate & 135.1 & -240.19 & 239.81 & 667.10 & 0.00 \\
\hline Ornstein-Uhlbeck multiple rate & 142.24 & -242.49 & -427.29 & 0.00 & 0.99 \\
\hline Ecological release & 129.60 & -229.20 & 250.80 & 678.09 & 0.00 \\
\hline Release and radiate & 135.48 & -228.97 & -413.77 & 13.52 & 0.00 \\
\hline Ecological constraint & 123.47 & -216.94 & 263.05 & 690.34 & 0.00 \\
\hline Radiation \& ecological constraint & 125.51 & -209.02 & -393.82 & 33.47 & 0.00 \\
\hline Brownian motion/early burst & 121.06 & -222.13 & -185.47 & 241.82 & 0.00 \\
\hline Early burst/Brownian motion & 121.78 & -223.55 & -186.89 & 240.40 & 0.00 \\
\hline
\end{tabular}


Table 4 Rates of shape change in the first three PC axes for the Caribbean radiation and Eastern Pacific Clade of Apogonidae following separation by the Isthmus of Panama

\begin{tabular}{|c|c|c|c|c|}
\hline Area & PC1 & PC2 & PC3 & Mean \\
\hline \multicolumn{5}{|c|}{ Legacy calibrated phylogeny } \\
\hline Caribbean & 3.47E-05 & $7.21 \mathrm{E}-06$ & $2.04 \mathrm{E}-05$ & 2.07E-05 \\
\hline Eastern Pacific & $3.72 \mathrm{E}-05$ & 4.01E-05 & $3.03 \mathrm{E}-05$ & $3.59 \mathrm{E}-05$ \\
\hline \multicolumn{5}{|c|}{ Isthmus calibrated phylogeny } \\
\hline Caribbean & 5.07E-05 & 1.07E-04 & $3.01 \mathrm{E}-05$ & $6.25 \mathrm{E}-05$ \\
\hline Eastern Pacific & $5.16 \mathrm{E}-05$ & $5.58 \mathrm{E}-05$ & 4.12E-05 & 4.97E-05 \\
\hline
\end{tabular}

at least partially due to application of the calibrations at deeper nodes in the phylogeny, and in the case of Eleotridae, to the use of multiple calibrations. The legacy calibrated estimates are probably the more accurate inferences. Errors propagated by legacy calibrations are small [9], and are generally preferable to using a biogeographic calibration, particularly when the legacy estimates derive from well-dated fossils and are applied at multiple nodes. Also, fossils provide truly independent data for calibration estimates. A calibration based on a biogeographic event is independent from organismal phylogeny, however given that organismal evolutionary patterns may be greatly affected by biogeographic events, and also that phylogenies are often themselves used to corroborate the dating of such events, the use of fossil based calibrations, even legacy calibrations, is preferable.

Ecological tolerance among the transisthmian lineages does not correlate with divergence time. New World species of Apogonidae (genera Apogon, Astrapogon, Phaeoptyx, Paroncheilus, and Zapogon) are all marine, found in shallow coral or rocky reef habitats in their respective seas $[42,43]$. Eleotridae are generally more euryhaline, and inhabit brackish and freshwater as well as salt. Eleotris are found in nearshore fresh and brackish habitats, including mangrove stands, as well as shallow marine water. Dormitator inhabit marshes, estuaries, and rivers, and can tolerate seawater. Gobiomorus are primarily found in freshwater rivers and lakes, including landlocked populations, but may also inhabit brackish habitats [44]. With the Isthmus of Panama gradually uplifting, likely in several separate blocks, it follows that the deeper-dwelling marine species would be separated first, followed by shallower ones, and then finally the fresh to brackish water species would diverge as their drainage systems separated into westward and eastward flowing, a pattern detected among multiple pairs of transisthmian snapping shrimp [45]. I did not detect that pattern among sleepers or cardinalfishes. The wholly marine Apogonidae show divergence of the Eastern Pacific clade from their Caribbean relatives at $12.5 \mathrm{Ma}$ (legacy dating)/8.2 Ma (isthmus dating), with isolation of the crown Eastern Pacific clade complete by $7.6 \mathrm{Ma}$ (legacy dating)/5.1 Ma (isthmus dating). Eleotris, the genus with the highest saltwater tolerance among those examined, includes a geminate divergence date estimate of $10.3 \mathrm{Ma}$ (legacy)/ 6.4 (isthmus). Intermediate is Dormitator, with the youngest estimated divergence of 7.6 Ma (legacy)/ 5.1 (isthmus), and the most freshwater pair, in Gobiomorus, exhibits the oldest estimated split date at 15.1 Ma (legacy)/ 9.9 (isthmus). There is no clear pattern among these taxa relating salt tolerance to transisthmian divergence, but given that the closure of the Isthmus was a complex, protracted process, it is not surprising that the responses of animal taxa affected would be idiosyncratic and variable.

\section{Patterns and rates of transisthmian morphological divergence}

Geometric morphometric data provide an overall assessment of comparative shape change, and are useful for revealing subtle shifts in organismal morphology. Among the transisthmian lineages examined here, expressions of morphological change are mosaic and varied, and do not show a common pattern among disparate taxa. In Eleotridae, transisthmian pairs show changes in head depth and width as well as body depth in Dormitator; head elongation and relative head/tail proportions in Eleotris; and a combination of overall width and head/tail displacement in Gobiomorus. All the changes are slight, and do not seem to reflect a single overarching pattern of change among all the pairs. The changes are statistically significant by range in the MANOVA (or nearly so in Gobiomorus), but not consistent among geminates. I did not apply phylogenetic correction to the independent transisthmian comparisons in Eleotridae, but for the nested patterns in Apogonidae, I applied phylogenetic corrections both to the PCA and to the MANOVA, using a subset of Apogonidae for which I had both molecular and morphometric data. After correction for the nested phylogenetic relationships, MANOVAs of comparisons among ranges were not significant.

The few previous studies of morphological change in transisthmian taxa have yielded similar results, with geminate species generally being morphometrically distinguishable, but without clear trends in shape or size change $[6-8,46]$. Rather than phenotypic differences, the primary consistent distinction among the transisthmian marine taxa reviewed by [3], was a change in maternal provisioning of eggs, such that eggs in the higher primary productivity environment (Eastern Pacific) were smaller and had lower maternal provisioning than those in the more nutrient-poor regime (Caribbean). This trend appears to hold not just for modern taxa, but for fossil species as well, with egg size decreasing in the Eastern Pacific roughly two million years ago [47]. In the current analysis, I found that the best-fitting model of morphological change, 
regardless of phylogenetic calibration method, postulated a rate shift at closure of the Isthmus of Panama, and modeled change as variation around a selective optimum (OrnsteinUhlbeck).

A final, potentially very important factor shaping patterns of morphology and ecology across the Isthmus is extinction. Ecologically, generalist taxa are less susceptible to extinction than specialists when confronted with habitat change [48]. Sleepers and cardinalfishes are both widely distributed groups, with high diversification rates (Apogonidae, [23]), wide ecological tolerances (Eleotridae, [44]), and generalist feeding strategies [42-44]. Although impossible to measure from phylogenetic reconstructions based on extant taxa, extinction of more specialized or canalized phenotypes would be expected in a period of tectonic upheaval and environmental change. In the cases of Apogonidae and Eleotridae, their generalist ecological tolerances likely contributed to their persistence and radiation on both sides of the Isthmus of Panama, even after Isthmus closure and associated environmental change.

\section{Conclusions}

Calibrated organismal phylogenies have been used extensively to estimate when marine populations were split by the closure of the Isthmus of Panama, with results indicating most commonly that populations diverged earlier than the canonical data of final Isthmus closure at 3.1 Ma [3]. Ongoing geological and evolutionary studies are revealing that the closure of the Isthmus was a complex tectonic event, with varied effects on marine (and terrestrial, [4]) faunas. I show that for two families of fishes, Eleotridae and Apogonidae, transisthmian lineages split at different times throughout the Miocene, that the divergence ages are not correlated to ecology, and that morphometric distinctions are detectable among geminate taxa. I estimate the timing of phylogenetic events using both legacy fossil based calibrations and a biogeographic calibration, and find that the legacy calibrations produce more precise dates that are more congruent with estimates from previous studies. I also demonstrate that among Apogonidae, fits of evolutionary models to the phylogeny show that rates of morphometric change shifted at Isthmus closure, variably among component axes of change, with acceleration of the rate of shape change among taxa in the Eastern Pacific.

\section{Additional file}

Additional file 1: Table S1. Sequences used for phylogenetic analysis of Eleotridae; GenBank accession numbers are listed for each gene. Table S2. Sequences used for phylogenetic analysis of Apogonidae; GenBank accession numbers are listed for each gene. Table S3. Species examined for morphometric analysis. Car = Caribbean; EPac = Eastern Pacific; MED = Mediterranean; UF = Florida Museum of Natural History. (DOCX $115 \mathrm{~kb}$ )

\section{Abbreviations}

ANSP: Academy of Natural Sciences, Philadelphia, Pennsylvania, USA; FMNH: Field Museum of Natural History, Chicago, Illinois, USA; LACM: Natural History Museum of Los Angeles County, Los Angeles, California, USA; UF: Florida Museum of Natural History, Gainesville, Florida, USA

\section{Acknowledgements}

I thank M. Sabaj-Perez (ANSP), C. McMahan (FMNH), R. Feeney (LACM), and R. Robins (UF) for providing specimen loans. The editor and three anonymous reviewers provided careful comments and suggestions that improved the quality of the manuscript.

\section{Author contributions}

Christine Thacker performed all portions of this study.

\section{Funding}

Funding for this study was provided by the National Science Foundation (NSF DEB 0108416) and by grants from the W. M. Keck and R. M. Parsons Foundations.

\section{Availability of data and materials}

All data generated or analyzed during this study are included in this published article [and its additional files].

\section{Competing interests}

The author declares that she has no competing interests.

\section{Consent for publication}

Not applicable.

Ethics approval and consent to participate

Not applicable.

\section{Publisher's Note}

Springer Nature remains neutral with regard to jurisdictional claims in published maps and institutional affiliations.

Received: 3 August 2016 Accepted: 25 April 2017

Published online: 10 May 2017

\section{References}

1. Coates AG, Stallard RF. How old is the isthmus of Panama? Bull Mar Sci. 2013;89(4):801-14.

2. Floeter SR, Rocha LA, Robertson DR, Joyeux JC, Smith-Vaniz WF, Wirtz P, Edwards AJ, Barreiros JP, Ferreira CEL, Gasparini JL, Brito A, Falcon JM, Bowen BW, Bernardi G. Atlantic reef fish biogeography and evolution. J Biogeogr. 2008;35:22-47.

3. Lessios HA. The great American schism: divergence of marine organisms after the rise of the central American isthmus. Annu Rev Ecol Evol Syst. 2008;39:63-92.

4. Bacon CD, Silvestro D, Jaramillo C, Smith BT, Chakrabarty P, Antonelli A. Biological evidence supports an early and complex emergence of the isthmus of Panama. Proc Natl Acad Sci. 2015;112(19):6110-5.

5. Cowman PF, Bellwood DR. Vicariance across major marine biogeographic barriers: temporal concordance and relative intensity of hard versus soft barriers. Proc R Soc Lond B. 2013;280(1768):20131541.

6. Vergara-Solana FJ, García-Rodriguez FJ, Tavera JJ, De Lun E, De La CruzAgüero J. Molecular and morphometric systematics of Diapterus (Perciformes, Gerreidae). Zool Scr. 2014;43:338-50.

7. Tringali MD, Bert T, Seyoum S, Bermingham E, Bartolacci D. Molecular phylogenetics and ecological diversification of the Transisthmian fish genus Centropomus (Perciformes: Centropomidae). Mol Phylogenet Evol. 1999;13(1):193-207.

8. Marko PB, Jackson JB. Patterns of morphological diversity among and within arcid bivalve species pairs separated by the isthmus of Panama. J Paleontol. 2001;75(3):590-606

9. Thacker CE, Hardman MA. Molecular phylogeny of basal gobioid fishes: Rhyacichthyidae, Odontobutidae, Xenisthmidae, Eleotridae (Teleostei: Perciformes: Gobioidei). Mol Phylogenet Evol. 2005;37:858-71.

10. Mabuchi K, Fraser TH, Song H, Azuma Y, Nishida M. Revision of the systematics of the cardinalfishes (Percomorpha: Apogonidae) based on molecular analyses and comparative reevaluation of morphological characters. Zootaxa. 2014;3846(2):151-203. 
11. Thacker CE, Roje DM. Phylogeny of cardinalfishes (Teleostei: Gobiiformes: Apogonidae) and the evolution of visceral bioluminescence. Mol Phylogenet Evol. 2009;52:735-45.

12. Agorreta A, San Mauro D, Schliewen U, Van Tassell JL, Kovacic M, Zardoya R, Rüber L. Molecular phylogenetics of Gobioidei and phylogenetic placement of European gobies. Mol Phylogenet Evol. 2013;69:619-33.

13. Thacker CE. Phylogeny of Gobioidei and placement within Acanthomorpha, with a new classification and investigation of diversification and character evolution. Copeia. 2009;2009(1):93-104.

14. Cowman PF, Bellwood DR. Coral reefs as drivers of cladogenesis: expanding coral reefs, cryptic extinction events, and the development of biodiversity hotspots. J Evol Biol. 2011;24:2543-62

15. Schliep KP. Phangorn: phylogenetic analysis in R. Bioinformatics. 2011;27(4): 592-3.

16. Drummond AJ, Suchard MA, Xie D, Rambaut A. Bayesian phylogenetics with BEAUti and the BEAST 1.7. Mol Biol Evol. 2012;29(8):1969-73.

17. Graur D, Martin W. Reading the entrails of chickens: molecular timescales of evolution and the illusion of precision. Trends Genet. 2004;20:80-6.

18. Ho SYW. Calibrating molecular estimates of substitution rates and divergence times in birds. J Avian Biol. 2007;38:409-14.

19. Schenk JJ. Consequences of secondary calibrations on divergence time estimates. PLoS One. 11(1):e0148228.

20. Kondandaramaiah U. Tectonic calibrations in molecular dating. Curr Zool. 2011:57(1):116-24

21. Ho SYW, Tong K, Foster CSP, Ritchie AM, Lo N, Crisp MD. Biogeographic calibrations for the molecular clock. Biol Lett. 2015;11:20150194.

22. Hipsley CA, Müller J. Beyond fossil calibrations: realities of molecular clock practices in evolutionary biology. Front Genet. 2014;5:00138.

23. Thacker CE. Species and shape diversification are inversely correlated among gobies and cardinalfishes (Teleostei: Gobiiformes). Org Divers Evol. 2014;14:419-36.

24. Rambaut A: FigTree 1.3.1 1999. http://tree.bio.ed.ac.uk/software/figtree/. Accessed May 2015.

25. Thacker CE, Pezold F, Suttkus RD. Redescription of the dwarf neotropical eleotrid genus Leptophilypnus (Teleostei: Gobioidei), including a new species and comments on Microphilypnus. Copeia. 2006;2006(3):489-99.

26. Schneider CA, Rasband WS, Eliceiri KW. NIH image to ImageJ: 25 years of image analysis. Nat Methods. 2012;9(7):671-5.

27. Klingenberg CP. MorphoJ: an integrated software package for geometric morphometrics. Mol Ecol Resour. 2011;11:353-7.

28. Adams DC, Otarola-Castillo E. Geomorph: an R package for the collection and analysis of geometric morphometric shape data. Methods Ecol Evol. 2013;4:393-9.

29. Harmon LJ, Weir JT, Brock CD, Glor RE, Challenger W. GEIGER: investigating evolutionary radiations. Bioinformatics. 2008;24:129-31.

30. Revell $L$. Phytools: an R package for phylogenetic comparative biology (and other things). Methods Ecol Evol. 2012;3:217-23.

31. Clavel J, Escarguel G, Merceron G. mvMORPH: an R package for fitting multivariate evolutionary models to morphometric data. Methods Ecol Evol. 2015:6(11):1311-9.

32. Slater GJ. Phylogenetic evidence for a shift in the mode of mammalian body size evolution at the cretaceous-Palaeogene boundary. Methods Ecol Evol. 2013;4:734-44.

33. Blomberg SP, Garland T, Ives AR. Testing for phylogenetic signal in comparative data: behavioral traits are more labile. Evolution. 2003;57(4):717-45.

34. Harmon LJ, Losos JB, Davies TJ, Gillespie RG, Gittleman JL, Jennings WB, Kozak KH, McPeek MA, Moreno-Roark F, Near TJ, Purvis A, Ricklefs RE, Schluter D, Schulte JA III, Seehausen O, Sidlauskas BL, Torres-Carvajal O, Weir $\mathrm{JT}$, Mooers AO. Early bursts of body size and shape evolution are rare in comparative data. Evolution. 2010;64(8):2385-96.

35. Burnham KP, Anderson DR. Model selection and Multimodel inference. New York: Springer; 2002

36. Rocha LA, Robertson DR, Rocha CR, Van Tassell $J$, Craig MT, Bowen BW. Recent invasion of the tropical Atlantic by an Indo-Pacific coral reef fish. Mol Ecol. 2005:14:3921-8.

37. Cowman PF, Bellwood DR. The historical biogeography of coral reef fishes: global patterns of origination and dispersal. J Biogeogr. 2013;40:209-24.

38. Thacker CE. Biogeography of goby lineages (Gobiiformes: Gobioidei): origin, invasions and extinction throughout the Cenozoic. J Biogeogr. 2015;42: 1615-25.

39. Near TJ, Dornburg A, Eytan RI, Keck BP, Smith WL, Kuhn KL, Moore JA, Price SA, Burbrink FT, Friedman M, Wainwright PC. Phylogeny and tempo of diversification in the superradiation of spiny-rayed fishes. Proc Natl Acad Sci. 2013;110:12738-43.

40. Near TJ, Eytan Rl, Dornburg A, Kuhn KL, Moore JA, Davis MP, Wainwright PC, Friedman M, Smith WL. Resolution of ray-finned fish phylogeny and timing of diversification. Proc Natl Acad Sci. 2012;109:13698-703.

41. Betancur-R R, Broughton RE, Wiley EO, Carpenter K, Lopez JA, Li C, Holcroft $\mathrm{NI}$, Arcila D, Sanciangco M, Cureton JC II, Zhang F, Buser T, Campbell MA, Ballesteros JA, Roa-Varon A, Willis S, Borden WC, Rowley T, Reneau PC, Hough DJ, Lu G, Grande T, Arratia G, Orti G. The tree of life and a new classification of bony fishes. PLoS Curr. 2013;18:5.

42. Allen GR, Robertson DR. Fishes of the tropical Eastern Pacific. Honolulu: University of Hawaii Press; 1994.

43. Humann P. Reef fish identification-Florida Caribbean Bahamas. Jacksonville: New World Publications; 1994.

44. Bussing WA. Peces de las aguas continentales de Costa Rica [freshwater fishes of Costa Rica]. 2nd ed. San José Costa Rica: Editorial de la Universidad de Costa Rica; 1998.

45. Knowlton NK, Weight LA. New dates and new rates for divergence across the isthmus of Panama. Proc R Soc Lond B. 1998;265:2257-63.

46. Lessios HA, Weinberg JR. Genetic and morphological divergence among morphotypes of the isopod Excirolana on the two sides of the isthmus of Panama. Evolution. 1994:48(3):530-48.

47. Moran AL. Egg size evolution in tropical American arcid bivalves: the comparative method and the fossil record. Evolution. 2004;58(12):2718-33.

48. Munday PL. Habitat loss, resource specialization, and extinction on coral reefs. Glob Chang Biol. 2004;10(10):1642-7.

\section{Submit your next manuscript to BioMed Central and we will help you at every step:}

- We accept pre-submission inquiries

- Our selector tool helps you to find the most relevant journal

- We provide round the clock customer support

- Convenient online submission

- Thorough peer review

- Inclusion in PubMed and all major indexing services

- Maximum visibility for your research

Submit your manuscript at www.biomedcentral.com/submit
) Biomed Central 